\title{
Comparative variation of Phoma medicaginis Malbr. \& Roum. var. medicaginis Boerema for cultural characteristics and virulence to roots and crowns of alfalfa ${ }^{1,2}$
}

\author{
Rocío del P. Rodríguez $z^{3}$
}

\author{
J. Agric. Univ. P.R. 89(3-4):229-242 (2005)
}

\begin{abstract}
The in vitro and in vivo variation of selected isolates of Phoma medicaginis var. medicaginis was studied in controlled environmental conditions. Isolates were relatively stable in morphology and pigmentation of the colony but varied more in final diameter of the colony, rate of growth and sporulation. The isolate, the organ and geographic location from which it was obtained were significant sources of variation. All isolates caused root and crown rot symptoms in growth chamber and greenhouse experiments. Differences in virulence among isolates were expressed in the length of root lesions. Plant dry weights were reduced by $82 \%$ in greenhouse trials.
\end{abstract}

Key words: spring black-stem, Phoma medicaginis var. medicaginis, alfalfa, Medicago sativa $\mathrm{L}$.

\section{RESUMEN}

\begin{abstract}
Variación comparativa de Phoma medicaginis Malbr.\& Roum. var. medicaginis Boerema para características culturales y virulencia a las raíces y coronas de alfalfa
\end{abstract}

La variación in vitro e in vivo de aislados seleccionados de Phoma medicaginis var. medicaginis se estudió en condiciones ambientales controladas. Los aislados fueron relativamente estables en morfología y pigmentación de la colonia pero variaron más en el diámetro final de la colonia, la tasa de crecimiento y la esporulación. El aislado, el órgano y la localidad geográfica de donde se obtuvo fueron fuentes de variación significativa. Todos los aislados causaron síntomas de pudrición en las raíces y la corona en los experimentos en las cámaras de crecimiento y en el invernadero. Diferencias en la virulencia de los aislados se expresaron en el tamaño de las lesiones en la raíz. En las pruebas de invernadero el peso seco de las plantas se redujo en un $82 \%$.

${ }^{1}$ Manuscript submitted to Editorial Board 24 november 2004.

${ }^{2}$ This paper cover work carried out in the USDA Regional Pasture Research Laboratory, University Park, Pennsylvania as a complement of the author's thesis dissertation. Special acknowledgments to Dr. Kenneth T. Leath and the late Dr. Richard Hill, Jr., for their assistance and support with the manuscript and statistics.

${ }^{3}$ Phytopathologist (Ad-Honorem), Department of Crop Protection, P.O. Box 9030, University of Puerto Rico, Mayagüez, PR 00681-9030. 

Palabras clave: tallo-negro de primavera, Phoma medicaginis var. medicagi-
nis, alfalfa, Medicago sativa L.

\section{INTRODUCTION}

For many years, variation in Phoma medicaginis var. medicaginis (P.m. var. m.) has received considerable attention, particularly in studies comparing this fungus with the spring black-stem pathogen of red clover (Trifolium pretense L.). These studies showed conflicting results regarding the cultural and pathogenic variation of this pathogen in alfalfa. Schenck and Gerdemann (1956) found that 18 isolates of P.m. var. $m$. were uniform in appearance, and Johnson and Valleau (1933) reported cultural variability only in the red clover pathogen. Sprague (1929) observed that spores produced on the host varied in morphology, but those produced in culture did not. Conversely, Ellingboe (1959b) grouped isolates of P.m. var. $m$. from several locations into six cultural types, which he did not describe, and found differences in the pathogenicity and in the virulence of monoconidial lines from these isolates. Reitz (1948) reported similar observations, but data were not presented. Edmunds and Hanson (1960) reported that geographical origin and years of collection were sources of variation for the pathogenicity of P.m. var. m.; however, the concentration of spores in the inoculum was not standardized.

Variation due to organ of origin was observed by Cormack (1945), who reported slight to moderate foliar infections induced by isolates from the leaf, stem, root, seed and soil. The differential response of leaves excised from three varieties of alfalfa to seed isolates of P.m. var. $m$. led Mead and Cormack (1961) to conclude that parasitic strains occurred in this fungus. Similarly, Gray et al. (1990) in their study with excised alfalfa trifoliates concluded that isolates from different organs and locations varied significantly in their ability to induce symptoms and in the density of spores produced in potato dextrose agar (PDA). However, these same authors acknowledged a significant difference in spore production, but no attempt to standardize the inoculum was reported. Conversely, Kernkamp and Hemerick (1953) found no differences in the pathogenicity of isolates from different geographical areas and plant organs.

Previous studies (Rodríguez et al., 1990, 1992) showed the important role that this foliar pathogen can have in the root and crown rot diseases of alfalfa. Because of disagreement in the literature concerning variation in P.m. var. $m$., this study was conducted to determine the variation in cultural characteristics of this fungus, and to find whether differences in pathogenicity and/or virulence to the roots and crowns of alfalfa were evident. 


\section{MATERIALS AND METHODS}

Plants of alfalfa showing leaf spots and black-stem symptoms were randomly collected from fields in Bradford, Centre and Lycoming counties in Pennsylvania. Roots and crowns were washed with detergent and rinsed in running tap water. Portions of these organs with rot symptoms were immersed for $5 \mathrm{~min}$ in $0.5 \%$ sodium hypochlorite, rinsed in sterile distilled water (SDW), and the superficial tissues were excised thus exposing the necrotic interior tissues for isolation. Pieces of tissues from these areas were plated on water agar and incubated at $21^{\circ} \mathrm{C}$ for two to four weeks. Leaves and stems were treated for 3 min in $0.5 \%$ sodium hyprochlorite, rinsed and placed in moist chambers for 48 $\mathrm{h}$ at room temperature.

Cultures of P.m. var. $m$. were also obtained directly on PDA by transferring spores from the picnidia formed in the host tissues. All isolates were stored on silica gel (Perkins, 1962) and the collection was expanded with isolates received from other states and Canada.

Identification of P.m. var. $m$. isolates was based on the available descriptions for this pathogen (Barnett and Hunter, 1972; Boerema, 1965, 1976). A typical and some atypical isolates were sent for identification and corroboration to Dr. Gerhard H. Boerema in the Netherlands.

Cultural characters. Nineteen isolates from Pennsylvania representing different locations and plant organs and 10 isolates from other geographical areas were activated from silica gel on PDA. Five-mm-diameter agar disks were cut from the periphery of the colony and transferred to plates containing oatmeal agar (OA). All isolates were treated similarly and incubated at $21^{\circ} \mathrm{C}$ for 30 days. Actively sporulating cultures were rinsed with SDW and the spore suspensions were further diluted and incubated in water agar (WA) for $48 \mathrm{~h}$. Single-spore cultures were prepared by transferring the germinated spores from the water-agar plates to the centers of plates containing PDA; these cultures were incubated at $21^{\circ} \mathrm{C}$ for 10 days. Daily growth was measured with a ruler and the rate of growth was estimated by the slope of the lineal equation of regression. For the sporulation measurements, 10 disks of 5-mm diameter were cut at half the radius of the colony and placed in test tubes containing $5 \mathrm{ml}$ of SDW. Test tubes were shaken for $1 \mathrm{~min}$ and the number of spores per square millimeter was estimated by using the hemocytometer. Pigmentation of the colony was determined by using the color nomenclature of Rayner (1970) and the appearance of the colony growth was assessed visually.

Experimental design was that of a randomized block, in which each shelf of the incubator constituted a replicate, and the isolates were evaluated in separate trials. The trial with the Pennsylvania isolates 
included five replicates with six single-spore cultures per replicate; the trial with isolates from other areas had four replicates with five singlespore cultures per replicate. The variation among isolates was determined by the analysis of variance. Because variation in the experimental conditions among trials may have occurred, an analysis was done to test the significance of the variation among trials. When no significant differences occurred among trials, then a partition analysis was conducted to determine whether organ and location of origin of the isolates were sources of variation. Differences among means for organ and location, as well as the means for isolates, were determined by the Scheffe's test at $\mathrm{P}<0.05$. The relationship between the variables studied was determined by using the correlation analysis.

Root inoculations in the growth chamber. Clonal plants from cultivar Iroquois were used in these experiments. Stem cuttings were disinfested by a 1-min immersion in 70\% ethanol, 20-min in hydrogen peroxide and three 10-min rinses in SDW. Rooting occurred in Hoagland solution agar contained in large test tubes (2.1-cm diameter $\times$ 19.8-cm depth). After one month, plants were carefully removed from the test tubes, their roots washed in SDW and placed in the slant-board system (Kendall and Leath, 1974). Plants were grown for an additional two weeks before inoculation. Seventeen isolates from several geographical locations and from different plant organs were included. Monoconidial lines, typical of each isolate and obtained from the previous trial, were used. Inoculum was produced on sterile pieces of stem of alfalfa (Rodríguez et al., 1990). Pieces were used as inoculum after 25 days when fully colonized by the fungus and picnidia were formed.

For inoculation, wounded and non-wounded roots of 6-week-old plants were inoculated with the isolates. For wounding, roots were stabbed with a 0.15 -mm-diameter needle, and the colonized piece of stem was placed on the wounded area. Plants were kept in the growth chamber for seven days, after which time length of the lesions were measured with a ruler. Each isolate was tested on one plant with six inoculated roots, and half of the roots were wounded. This experiment was repeated three times. The data were subjected to an analysis of variance, and the means compared with the Tukey Studentized test at $\mathrm{P}<0.05$.

The sporulation of each isolate in the piece of stem was estimated by immersing three stem pieces in a test tube containing $5 \mathrm{ml}$ of SDW and shaking for $1 \mathrm{~min}$. The number of spores per milliliter in this suspension was estimated with the hemocytometer and divided by three. This procedure was repeated four times, and the data analyzed with the analysis of variance.

Root inoculation in the greenhouse. Clonal plants of cultivar Iroquois were produced in the greenhouse. Seven isolates were selected on the 
basis of their performance in the growth-chamber studies. Inoculum was prepared by scraping the surface of the 30-day-old single-spore cultures growing on $\mathrm{OA}$ and then rinsing with SDW. For all isolates, concentration of inoculum was adjusted to $2 \times 10^{6}$ spores $/ \mathrm{ml}$ by using the hemocytometer. For inoculation, two-month-old plants were carefully removed from the rooting medium and their roots washed in tap water. Roots of test plants were wounded by pressing them with a file-card (wire brush used to clean files) immediately prior to immersion for $1 \mathrm{~h}$ in the designated spore suspension. Control plants were immersed in SDW. After treatment, plants were planted in clay pots containing $450 \mathrm{~g}$ of a vermiculite peat-potting mixture, placed in the mist chamber for two days at approximately $21^{\circ} \mathrm{C}$, then returned to the greenhouse for one month.

Treatments were arranged in a randomized block design with seven replications. Dry weights of foliage and roots were analyzed with the analysis of variance, and the means of isolates compared with the Tukey Studentized test at $\mathrm{P}<0.05$.

Crown inoculations. Seed plants from cultivar Iroquois were grown in slant boards. Monoconidial lines from isolates BTL-2 (leaf), BTS-2 (stem), BTC-2 (crown), and BTR-2 (root) were grown on OA until sporulating actively. Inoculum consisted of a mass of spores on the tip of a flamed dissecting needle, and plants were inoculated by being stabbed in the crown with the needle-borne spores approximately $3 \mathrm{~mm}$ deep. Control plants were similarly stabbed but with a needle free of spores. The plants were returned to the growth chamber for one month. For evaluation, stems and roots were serially cross-sectioned, starting from the tip and progressing toward the crown until necrosis was observed. The length of internal discoloration from the inoculation site was measured with a ruler.

The experimental design consisted of four isolate treatments replicated six times with six plants per replication arranged in a randomized block design. Data on length of internal necrosis were subjected to the analysis of variance, and the means of isolates compared by using the Tukey Studentized test at $\mathrm{P}<0.05$.

For all in vivo studies, random samples were obtained from the inoculated plants and disinfested in $0.25 \%$ sodium hypochlorite for $1 \mathrm{~min}$, and rinsed in SDW. Pieces of these samples were plated on PDA and examined after 15 days at $21^{\circ} \mathrm{C}$ for microbial contaminants.

\section{RESULTS AND DISCUSSION}

Phoma medicaginis var. medicaginis was readily isolated from the leaves, stems and roots of alfalfa. Bacteria were more frequently associated with diseased crown tissues. The cultural characters of most fungal colonies obtained from the isolations were typical of $P . m$. var. $m$. Colonies were dark grey with a tint of olive (olivaceous grey-No. 121), 
with smooth regular margins, and sparse aerial mycelium that became evanescent near sporulation. Abundant gregarious fertile picnidia were formed scattered over the surface of the colony. Crystals beneath the colony (Figure 1A) were produced by all isolates that showed the typical cultural features of the black-stem pathogen of alfalfa. Type isolates with corroborated identification were used as a reference for subsequent identifications.

Cultural characters. After 10 days of incubation, single-spore cultures of isolates from Pennsylvania showed moderate cultural stability for color and morphology of the colony. Predominantly, they were similar to the parent culture of the isolate, but variants occurred at low frequency. Shades different from the predominant grey olivaceous pigmentation and dark sectors were observed (Figure 1B). Variation in morphology was shown by some cultures in which the mycelium grew tightly packed together thus giving the colony a leathery texture. Cultures showing this growth habit had smaller diameters but appeared thicker than the typical type, and the surface of the medium at the margins of the colony was slightly depressed (Figure 1C). Another distinct variant occurred in the stem isolate from Rock Springs. This culture was olive with a tint of grey (grey olivaceous No. 107), produced abundant fluffy aerial mycelium, and did not sporulate (Figure 1B).

Single-spore cultures from isolates from other geographical locations varied less in morphology than those from Pennsylvania, and variants were rarely observed. All isolates conformed to the morphological characteristics typical of P.m. var. m.; however, differences in shades of pigmentation among some isolates also occurred. Isolates from Wyoming were consistently light olivaceous grey, thus suggesting a standard pigmentation in these isolates.

The analysis of Pennsylvania isolates for diameter of the colony, rate of growth and sporulation of single-spore cultures showed that the isolates were the major sources of variation and that variation due to the experimental conditions among trials was not significant (Table 1). Organ of origin significantly affected diameter of the colony, rate of growth and sporulation. Similarly, location was a significant source of variation for diameter of the colony and for rate of growth, but it had no effect on the in vitro sporulation. Location had more effect on the diameter of the colony and the rate of growth than did organ of origin, as evidenced by the higher mean square values obtained for the location of the isolates.

Overall means for organ of origin showed that isolates from the crown and root grew faster, attaining larger colony diameters than those from the leaf, and that root and stem isolates sporulated more than leaf and crown isolates (Table 2a, b, and c). Means for location indicated that isolates from Rock Springs had smaller diameters than those from other 

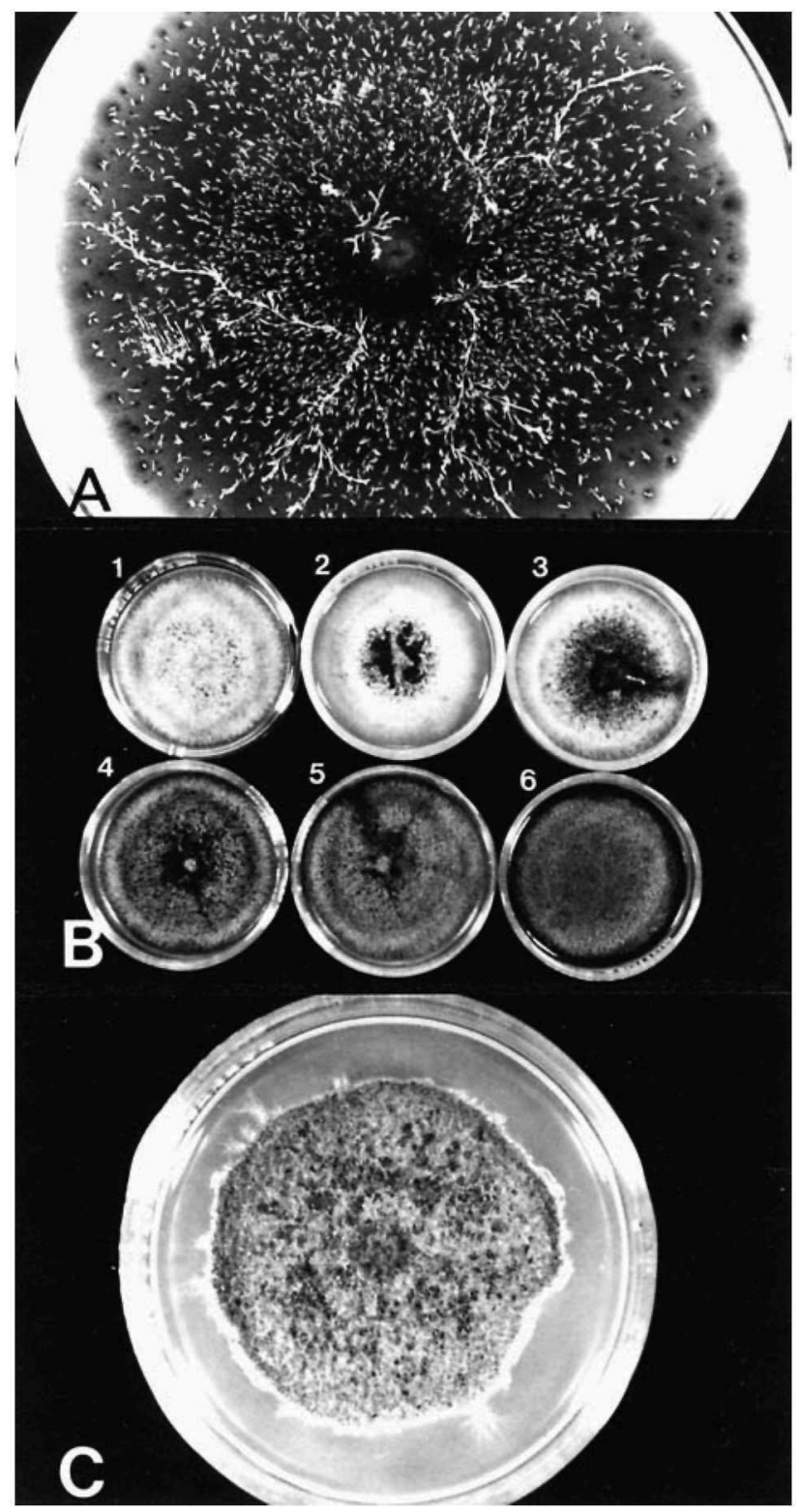

FIGURE 1. Cultural characteristies of Phoma medicaginis var medicaginis and variants. A. Crystals formed at the bottom of the colony typical of the fungus. B. Variants in pigmentation of single-spore cultures. 1 to 3 . Lighter shades showing stromatic and moist center associated with high sporulating zones; 4 and 5 . Cultures with characteristic features of this fungus; 6 . Mycelial type from the Rock Springs isolate. C. Morphological variant. 
TABLE 1.-Statistics from the analysis of variance for diameter of the colony, rate of growth and sporulation of isolates from Pennsylvania of Phoma medicaginis var. medicaginis grown on potato dextrose agar at $21^{\circ} \mathrm{C}$.

\begin{tabular}{lrlcc}
\hline & & \multicolumn{3}{c}{ Mean Square } \\
\cline { 3 - 5 } Source $^{1}$ & DF & Diameter & Rate & Sporulation \\
\hline Trials & 3 & 0.1920 & 0.0024 & 81.77 \\
Rep*Trials & 16 & 0.0927 & 0.0212 & 130.95 \\
Isolates & 15 & $3.6048^{* *}$ & $0.1207^{* *}$ & $1466.09^{* *}$ \\
Location & 5 & $8.0731^{* *}$ & $0.2261^{* *}$ & 111.39 \\
Organ & 3 & $1.3483^{* *}$ & $0.0612^{* * *}$ & $4881.53^{* * *}$ \\
Location* Organ & 7 & $1.3803^{* *}$ & $0.0709^{* *}$ & $969.98^{* *}$ \\
Culture (Is) & 95 & 0.1838 & 0.0042 & 50.42 \\
Error & 440 & 0.1363 & 0.0033 & 46.77 \\
\hline
\end{tabular}

${ }^{1}$ Rep $=$ Replications.

** Significant at $\mathrm{P}<0.01$.

locations, and isolates from the Taylor farm grew more slowly than the others (Table $2 \mathrm{a}, \mathrm{b}$ ). Interactions between organ and location were detected for diameter of the colony, rate of growth and sporulation (Table 1). This interaction indicates that deviations occurred from the pattern suggested by the overall means; hence the organ of origin of the isolate was not always the major source of variation.

The correlation analysis showed a linear relationship between the colony diameter and growth rate $(\mathrm{r}=0.72, \mathrm{P}<0.01)$. Fast growing cultures tended to have larger diameters and vice versa. The first three days after spore transfer had a great influence on the rate of growth and the final diameter of the colony. Cultures with a prolonged lag phase tended to have colonies of smaller diameters. Similar observations were reported by Ellingboe (1959a), who found that differences in growth among single-spore cultures of $P . m$. var. $m$. reside in the first 24 to $72 \mathrm{~h}$ after transfer. Some of the cultures showing an extended lag phase had smaller colony diameters at the end of the trial. Others overcame the lag period with a rapid growth phase that yielded a final colony diameter similar to that of cultures without a prolonged lag phase. These cultures thus had higher growth rates than did cultures that produced the same size colony but had shorter lag periods.

Sporulation of the isolates was not correlated with diameter of the colony $(\mathrm{r}=0.04, \mathrm{P}>0.01)$, but a negative correlation with the rate of growth was found $(\mathrm{r}=-0.16, \mathrm{P}<0.01)$. However, only $3 \%$ of the variation in the sporulation was explained by the rate of growth, thus indicating that faster growing isolates did not always sporulate less and vice versa. This finding indicated that other factors were more determinative for conidial production. 
TABLE 2.-Effect of location and organ of origin on colony diameter, rate of growth, and sporulation of Phoma medicaginis var. medicaginis grown on potato dextrose agar at $21^{\circ} \mathrm{C}$.

\begin{tabular}{|c|c|c|c|c|c|}
\hline \multirow{2}{*}{$\begin{array}{l}\text { Location } \\
\text { County-Farm }\end{array}$} & \multicolumn{5}{|c|}{ Organ } \\
\hline & Crown & Root & Stem & Leaf & Mean \\
\hline \multicolumn{6}{|c|}{ a. Diameter of the colony ${ }^{1}(\mathrm{~mm})$} \\
\hline Bradford-Lewis & $45 \mathrm{a}^{2}$ & $45 \mathrm{a}$ & $49 \mathrm{a}$ & 46 a & $46 \mathrm{ab}$ \\
\hline Mifflin-_ & - & - & 48 a & - & 48 a \\
\hline Bradford-Thomson & $49 a$ & $47 \mathrm{a}$ & $47 \mathrm{ab}$ & $46 \mathrm{a}$ & $47 \mathrm{a}$ \\
\hline Bradford-Taylor & $50 a$ & $49 \mathrm{a}$ & $45 \mathrm{ab}$ & $37 \mathrm{~b}$ & $45 \mathrm{~b}$ \\
\hline Lycoming-Young & $46 \mathrm{a}$ & $47 \mathrm{a}$ & $43 \mathrm{bc}$ & $44 \mathrm{a}$ & $45 \mathrm{~b}$ \\
\hline Centre-Rock Springs & - & - & $42 \mathrm{c}$ & $43 \mathrm{a}$ & $43 \mathrm{c}$ \\
\hline Mean & $48 \mathrm{~A}^{3}$ & $47 \mathrm{~A}$ & $46 \mathrm{~A}$ & $43 \mathrm{~B}$ & \\
\hline \multicolumn{6}{|l|}{ b. Rate of growth ${ }^{1}(\mathrm{~mm})$. } \\
\hline Bradford-Lewis & $5.4 \mathrm{a}^{2}$ & $5.3 \mathrm{a}$ & $6.2 \mathrm{a}$ & $5.4 \mathrm{a}$ & $5.6 \mathrm{a}$ \\
\hline Mifflin- & - & - & $6.1 \mathrm{a}$ & - & $6.1 \mathrm{~b}$ \\
\hline Bradford-Thomson & $6.0 \mathrm{a}$ & $5.7 \mathrm{a}$ & $5.6 \mathrm{ab}$ & $5.4 \mathrm{a}$ & $5.7 \mathrm{ab}$ \\
\hline Bradford-Taylor & $6.1 \mathrm{a}$ & $5.9 \mathrm{a}$ & $4.5 \mathrm{c}$ & $3.6 \mathrm{~b}$ & $5.0 \mathrm{c}$ \\
\hline Lycoming-Young & $5.4 \mathrm{a}$ & $5.5 \mathrm{a}$ & $4.6 \mathrm{c}$ & $6.1 \mathrm{a}$ & $5.4 \mathrm{a}$ \\
\hline Centre-Rock Springs & - & - & $5.1 \mathrm{bc}$ & $5.7 \mathrm{a}$ & $5.4 \mathrm{a}$ \\
\hline Mean & $5.7 \mathrm{~A}^{3}$ & $5.6 \mathrm{~A}$ & $5.4 \mathrm{~B}$ & $5.2 \mathrm{~B}$ & \\
\hline \multicolumn{6}{|l|}{ c. Sporulation ${ }^{1}(\times 1000)$} \\
\hline Bradford-Lewis & $5.1 \mathrm{a}^{2}$ & $17.4 \mathrm{a}$ & $8.9 \mathrm{a}$ & $10.7 \mathrm{a}$ & $10.5 \mathrm{a}$ \\
\hline Mifflin- & - & - & $7.8 \mathrm{a}$ & - & $7.8 \mathrm{a}$ \\
\hline Bradford-Thomson & $4.0 \mathrm{a}$ & $21.0 \mathrm{a}$ & $11.9 \mathrm{a}$ & $2.2 \mathrm{a}$ & $9.8 \mathrm{a}$ \\
\hline Bradford-Taylor & $4.6 \mathrm{a}$ & $10.8 \mathrm{a}$ & $14.1 \mathrm{a}$ & $5.9 \mathrm{a}$ & $8.9 \mathrm{a}$ \\
\hline Lycoming-Young & $3.2 \mathrm{a}$ & $8.1 \mathrm{~b}$ & $26.8 \mathrm{~b}$ & $5.7 \mathrm{a}$ & $11.0 \mathrm{a}$ \\
\hline Centre-Rock Springs & - & - & $13.2 \mathrm{a}$ & $6.5 \mathrm{a}$ & $9.9 \mathrm{a}$ \\
\hline Mean & $4.2 \mathrm{~A}^{3}$ & $14.3 \mathrm{~B}$ & $13.8 \mathrm{~B}$ & $6.2 \mathrm{~A}$ & \\
\hline
\end{tabular}

\footnotetext{
${ }^{1}$ Average of 30 single-spore cultures per isolate.

${ }^{2}$ Means in a column with the same letter do not differ significantly at $\mathrm{P}<0.05$.

${ }^{3}$ Means in row with the same letter do not differ significantly at $\mathrm{P}<0.05$.
}

The comparison among isolates from other geographical locations showed influence of organ of origin on the parameters measured (Table 3 ). Leaf isolates tended to have higher growth rates whereas seed isolates grew more slowly and produced fewer spores. The stem isolates sporulated more and had smaller colony diameter. Variations from this trend also occurred, evidenced by the differences in the diameter of the colony of the Pennsylvania leaf isolate from those from New York and Kansas, as well as the differences in diameter of the colony of the root isolates from Prince Edward Island.

Root inoculations in the growth chamber. All isolates were pathogenic to the roots of alfalfa (Table 4 ). Wounding significantly enhanced 
TABLE 3.-Effect of geographic location and organ of origin on colony diameter, rate of growth, and sporulation of Phoma medicaginis var. medicaginis grown on potato dextrose agar at $21^{\circ} \mathrm{C}$.

\begin{tabular}{lclclc}
\hline Isolate & Location $^{1}$ & Organ & $\begin{array}{c}\text { Diam. }^{2} \\
(\mathrm{~mm})\end{array}$ & $\begin{array}{c}\text { Rate }^{2} \\
(\mathrm{~mm})\end{array}$ & $\begin{array}{c}\text { Sporulation }^{2} \\
(\times 1000)\end{array}$ \\
\hline KPL-2 & KS & Leaf & $50 \mathrm{a}^{3}$ & $6.4 \mathrm{a}$ & $10.0 \mathrm{a}$ \\
NY-873 & NY & Leaf & $50 \mathrm{a}$ & $7.1 \mathrm{a}$ & $3.4 \mathrm{~b}$ \\
PA-866 & PA & Leaf & $44 \mathrm{c}$ & $6.7 \mathrm{a}$ & $1.7 \mathrm{bc}$ \\
ILL-365 & IL & Stem & $45 \mathrm{c}$ & $6.0 \mathrm{ab}$ & $12.4 \mathrm{a}$ \\
MiS & MS & Stem & $45 \mathrm{c}$ & $4.7 \mathrm{~b}$ & $13.7 \mathrm{~d}$ \\
AS-6 & AB & Stem & $43 \mathrm{c}$ & $4.1 \mathrm{~b}$ & $11.6 \mathrm{a}$ \\
PEIR-366 & PE & Root & $43 \mathrm{c}$ & $5.2 \mathrm{~b}$ & $2.9 \mathrm{~b}$ \\
PEIR-381 & PE & Root & $48 \mathrm{~b}$ & $5.0 \mathrm{~b}$ & $1.4 \mathrm{c}$ \\
WSe-5 & WY & Root & $48 \mathrm{~b}$ & $3.7 \mathrm{bc}$ & $1.1 \mathrm{c}$ \\
WSe-11 & WY & Root & $47 \mathrm{~b}$ & $3.2 \mathrm{c}$ & $1.3 \mathrm{c}$ \\
\hline
\end{tabular}

${ }^{1} \mathrm{AB}=$ Alberta-Canada, $\mathrm{IL}=$ Illinois, $\mathrm{KS}=$ Kansas, $\mathrm{MS}=$ Mississippi, $\mathrm{NY}=$ New York, $\mathrm{PA}=$ Pennsylvania, $\mathrm{PE}=$ Prince Edward Island, $\mathrm{WY}=$ Wyoming.

${ }^{2}$ Average of 20 single-spore cultures per isolate.

${ }^{3}$ Means in a column with the same letter do not differ significantly at $\mathrm{P}<0.05$.

the development of disease $(\mathrm{F}=188.90, \mathrm{P}<0.01)$, and lesions in the wounded inoculated roots were longer than those in the non-wounded inoculated roots. The interaction between isolate and root treatment was not significant. With the two methods of inoculation, differences in virulence among isolates were detected. In non-wounded roots, the root isolate BTR-2 was the most virulent, inducing longer lesions than those induced by the other isolates. In the presence of wounds, isolate BTR2 and isolate MS showed extremes in virulence. Differences between the remaining isolates were not detected. For each isolate the mean for each inoculation method was calculated, demonstrating that isolate BTR-2 was the most virulent, inducing significantly longer lesions.

Differences were not detected among isolates for sporulation on stem pieces. Therefore, spore concentration was not likely the factor accounting for the differences detected in the length of lesion induced by some isolates. Mycelium functions as inoculum for most fungal pathogens; however, when using the stem pieces as inoculum, only very sparse mycelium was present along with abundant fertile picnidia. Therefore, conidia were considered to be the primary inoculum.

Root inoculations in the greenhouse. All isolates were pathogenic to wounded roots of alfalfa and caused significant loss in dry weights of roots and foliage (Table 5). However, significant differences among isolates were not detected. Different environmental conditions, methods of inoculation, and criteria of evaluation might explain the differences in the behavior of isolates when evaluated in the growth chamber and 
TABLE 4.-Effect of location and organ of origin of Phoma medicaginis var. medicaginis on the length of rot lesions in roots of clonal alfalfa plants, wounded and nonwounded, grown in slant boards in the growth chamber.

\begin{tabular}{|c|c|c|c|c|c|}
\hline \multirow[b]{2}{*}{ Isolate } & \multicolumn{2}{|c|}{ Source } & \multicolumn{3}{|c|}{ Length of lesion ${ }^{1}(\mathrm{~mm})$} \\
\hline & Location & Organ & $\mathrm{NW}^{2}$ & $W^{2}$ & Mean \\
\hline BTR-2 & Bradford, $\mathrm{Pa}$ & Root & $6 \mathrm{a}^{3}$ & $9 \mathrm{a}$ & $7.4 \mathrm{a}$ \\
\hline BTS-2 & Bradford, $\mathrm{Pa}$ & Stem & $4 \mathrm{~b}$ & $7 \mathrm{ab}$ & $5.3 \mathrm{~b}$ \\
\hline LYS & Lycoming, $\mathrm{Pa}$ & Stem & $3 \mathrm{~b}$ & $7 \mathrm{ab}$ & $5.0 \mathrm{bc}$ \\
\hline LYR & Lyeoming, $\mathrm{Pa}$ & Root & $4 \mathrm{~b}$ & $6 a b c$ & $5.0 \mathrm{bc}$ \\
\hline NY-873 & New York & Leaf & $3 \mathrm{~b}$ & $6 a b c$ & $4.6 \mathrm{bed}$ \\
\hline WSe-11 & Wyoming & Seed & $3 \mathrm{~b}$ & $5 \mathrm{bc}$ & $4.3 \mathrm{bcd}$ \\
\hline LYL & Lyeoming, $\mathrm{Pa}$ & Leaf & $3 \mathrm{~b}$ & $5 \mathrm{bc}$ & $3.9 \mathrm{bed}$ \\
\hline CRL & Centre, $\mathrm{Pa}$ & Leaf & $3 \mathrm{~b}$ & $5 \mathrm{bc}$ & $3.9 \mathrm{bcd}$ \\
\hline KPL-2 & Kansas & Leaf & $3 \mathrm{~b}$ & $5 \mathrm{bc}$ & 3.9 bed \\
\hline LYC & Lyeoming, $\mathrm{Pa}$ & Crown & $3 \mathrm{~b}$ & $5 \mathrm{bc}$ & $3.9 \mathrm{bed}$ \\
\hline PA-866 & Centre, $\mathrm{Pa}$ & Leaf & $3 \mathrm{~b}$ & $4 \mathrm{bc}$ & $3.8 \mathrm{bed}$ \\
\hline BTL-2 & Bradford, $\mathrm{Pa}$ & Leaf & $2 \mathrm{~b}$ & $5 \mathrm{bc}$ & $3.7 \mathrm{bcd}$ \\
\hline BTC-2 & Bradford, $\mathrm{Pa}$ & Crown & $2 \mathrm{~b}$ & 5 be & $3.7 \mathrm{bed}$ \\
\hline PEIR-366 & Prince Ed Island & Root & $2 \mathrm{~b}$ & $5 \mathrm{bc}$ & $3.5 \mathrm{bed}$ \\
\hline Ill-365 & Illinois & Stem & $2 \mathrm{~b}$ & $4 \mathrm{bc}$ & $3.3 \mathrm{~cd}$ \\
\hline MiS & Mississippi & Stem & $2 \mathrm{~b}$ & $4 \mathrm{bc}$ & $3.3 \mathrm{~cd}$ \\
\hline MS & Mifflin, $\mathrm{Pa}$ & Stem & $2 \mathrm{~b}$ & $3 \mathrm{c}$ & $2.7 \mathrm{~d}$ \\
\hline
\end{tabular}

${ }^{1}$ Average of three replications with three roots in each root treatment.

${ }^{2} \mathrm{NW}=$ non-wounded roots, $\mathrm{W}=$ wounded roots.

${ }^{3}$ Means in column followed by the same letter do not differ significantly at $\mathrm{P}<0.05$.

in the greenhouse. The more moderate temperatures, the reduced competition with other species, and the constant exposure of roots to inoculum in the growth chamber studies favored the fungus. Lengths

TABLE 5.-Effect of root inoculations with isolates of Phoma medicaginis var. medicaginis, on the root and foliar dry weights $(\mathrm{mg})$ of clonal alfalfa plants grown in the greenhouse.

\begin{tabular}{lllcc}
\hline Treatment & \multicolumn{1}{c}{ Location } & Organ & DWR & DWF \\
\hline Control & \multicolumn{1}{c}{-} & - & $229 \mathrm{a}^{2}$ & $360 \mathrm{a}$ \\
BTL-2 & Bradford, Pa-Thomson & Leaf & $75 \mathrm{~b}$ & $132 \mathrm{~b}$ \\
BTC-2 & Bradford, Pa-Thomson & Crown & $57 \mathrm{~b}$ & $109 \mathrm{~b}$ \\
BTS-2 & Bradford, Pa-Thomson & Stem & $50 \mathrm{~b}$ & $118 \mathrm{~b}$ \\
WSe-11 & Wyoming & Seed & $53 \mathrm{~b}$ & $90 \mathrm{~b}$ \\
PEIR-366 & Prince Edward Island & Root & $50 \mathrm{~b}$ & $73 \mathrm{~b}$ \\
BTR-2 & Bradford, Pa-Thomson & Root & $43 \mathrm{~b}$ & $83 \mathrm{~b}$ \\
KPL-2 & Kansas & Leaf & $41 \mathrm{~b}$ & $67 \mathrm{~b}$ \\
\hline
\end{tabular}

${ }^{1} \mathrm{DWR}=$ dry weight of roots, DWF $=$ dry weight of foliage.

${ }^{2}$ Means in a column with the same letter do not differ significantly at $\mathrm{P}<0.05$. 
of lesions probably did not reflect the overall impact of the infection on the host as much as dry weights did.

Crown inoculations. All isolates were pathogenic to the crowns of alfalfa grown in the growth chamber, but differences in the extent of external crown deterioration were not observed. However, differences occurred among the isolates in the length of the internal necrosis of the stem and into the upper taproot (Table 6). Extensive discoloration of the vascular tissues was detected in the stem following inoculations of the crowns with stem and leaf isolates, and only the leaf isolate extensively colonized the vascular tissue of the upper taproot. Fewer invasion of the vascular tissues of both organs was obtained when crowns were inoculated with root and crown isolates.

Problems in isolating the fungus from the inoculated plants were not encountered. For all in vivo studies the fungus was recovered from diseased tissues almost exclusively, thus indicating that the isolates of P.m. var. $m$. were responsible for the results obtained.

The variation in virulence among isolates reflects differences in the rate at which they infect the host tissues and possibly demonstrates differences also in their ability during early stages of the disease cycle to exploit the external nutritional environment provided by the roots. Isolates of P.m. var. $m$. in response to known concentrations of sugars and amino acids expressed changed morphology, growth and sporulation (Chung and Wilcoxson, 1971; Mead, 1962).

Significant differences in cultural characters and virulence to the roots were detected primarily in controlled environments. The relevance of this finding lies in the selection of isolates and inoculation environments for screening in the breeding programs. The cultures used in the in vivo studies were selected on the basis of the overall characteristics of the pathogen; the cultural variants were not tested. If these variants prove to be stable, they can be an important tool for studies on the genetics of this fungus.

TABLE 6.-Effect of crown inoculations with selected isolates of Phoma medicaginis var. medicaginis on the length of internal necrosis in the stems and taproots of alfalfa plants grown in slant boards in the growth chamber.

\begin{tabular}{|c|c|c|c|c|}
\hline \multirow[b]{2}{*}{ Isolate } & \multicolumn{2}{|l|}{ Source } & \multicolumn{2}{|c|}{ Length $(\mathrm{mm})^{1}$} \\
\hline & Location & Organ & Stem & Taproot \\
\hline BTL-2 & Bradford, Pa-Thomson & Leaf & $41 \mathrm{a}^{2}$ & $46 a$ \\
\hline BTS-2 & Bradford, Pa-Thomson & Stem & $40 \mathrm{a}$ & $27 \mathrm{~b}$ \\
\hline BTR-2 & Bradford, Pa-Thomson & Root & $29 \mathrm{~b}$ & $31 \mathrm{~b}$ \\
\hline BTC-2 & Bradford, Pa-Thomson & Crown & $29 \mathrm{~b}$ & $29 \mathrm{~b}$ \\
\hline
\end{tabular}

\footnotetext{
${ }^{1}$ Average of 36 plants.

${ }^{2}$ Means in a column followed by the same letter do not differ significantly at $\mathrm{P}<0.05$.
} 
Morphology has often been used as an indicator of variability in all living species. Variation among species of Sclerotium collected from different geographical areas was so evident and stable that the species could be differentiated by cultural characteristics, histochemical reactions and composition of sclerotia (Punja and Damiani, 1996). Daniel et al. (2003) reported that the phenotypic variations found in their studies with isolates from different geographical locations were derived asexually. Mutations, heterokariosis and parasexuality are proposed mechanisms of variations operating in the asexually reproducing fungi (Hansen and Smith, 1932). Sanderson and Srb (1965) demonstrated heterokariosis and parasexuality in P.m. var. $m$. using in vitro induced auxotrophic mutants. Little is known about the frequency or relevancy of heterokariosis in nature and few genera of imperfect fungi exhibit heterokariosis in natural populations (Caten and Jinks, 1966). Taylor et al. (1999) proposed that in nature most fungi are "clonal and recombining". Any of these mechanisms could have caused the variants observed. There is need for more research on the inheritance of P.m. var. $m$. to determine the actual mechanism taking place.

\section{LITERATURE CITED}

Barnett, H. L. and B. B. Hunter, 1972. Illustrated Genera of Imperfect Fungi. $3^{\text {rd }}$ ed. Burgess Publishing Co., Minneapolis, MN. 218 pp.

Boerema, G. H., 1976. The Phoma species studied in culture by Dr. R. W. G. Dennis. Trans. Br. Mycol. Soc. 67:289-319.

Boerema, G. H., M. M. J. Dorenbosch and L. Leffring, 1965. A comparative study of the black stem fungi on Lucerne and red clover and the foot rot fungus on pea. Neth. J. Plant Path. 71:79-89.

Caten, C. E. and J. L. Jinks, 1966. Heterokaryosis: Its significance in wild homothallic ascomycetes and fungi imperfecti. Trans. Br. Mycol. Soc. 49:81-93.

Chung, H. S. and R. D. Wilcoxson, 1971. Effects of temperature, light, carbon and nitrogen nutrition on reproduction in Phoma medicaginis. Mycopath. Et Mycol. Applic. 44:297-308.

Cormack, M. W., 1945. Studies on Ascochyta imperfecta, a seed and soil-borne parasite of alfalfa. Phytopathology 35:838-854.

Daniel, R., B. A. Wilson and D. M. Cahill, 2003. Phytophthora cinnamomi in native vegetation communities of southern Victoria-morphological variation and paragyny among isolates. Australasian Plant Pathology 32(3):403-409.

Edmunds, L. K. and E. W. Hanson. 1960. host range, pathogenicity and taxonomy of Ascochyta imperfecta. Phytopathology 50:105-108.

Ellingboe, A. H., 1959a. Studies on the growth of Phoma herbarum var. medicaginis in culture. Phytopathology 49:773-776.

Ellingboe, A. H., 1959b. A comparative study of the fungi causing the spring black stem disease of alfalfa and red clover. Phytopathology 49:767-770.

Gray, F. A., J. A. Fernández, and J. L. Horton, 1990. Variation among isolates of Phoma medicaginis var. medicaginis in spore production in vitro and symptom expression on excised leaves of alfalfa. Plant Dis. 74:668-670. 
Hansen, H. N. and R. E. Smith, 1932. The mechanism of variation in imperfect fungi: Botrytis cinerea. Phytopathology 22:953-964.

Johnson, E. M. and W. D. Valleau, 1933. Black stem of alfalfa, red clover and sweet clover. Ky. Agr. Exp. Sta. Bull. 339. 89 pp.

Kendall, W. A. and K. T. Leath, 1974. Slant-board culture methods for root observations of red clover. Crop Sci. 14:317-320.

Kernkamp, M. F. and G. A. Hemerick, 1953. The relation of Ascochyta imperfecta to alfalfa seed production in Minnesota. Phytopathology 43:378-382.

Mead, H. W.,1962. Studies on Ascochyta imperfecta Peck. Changes in physical characteristies of Canadian isolates on agar amended with various amino acids. Can. J. Bot. 40:1365-1370.

Mead, H. W. and M. W. Cormack, 1961. Studies on Ascochyta imperfecta Peck. Parasitic strains among fifty isolates from Canadian alfalfa seed. Can. J. Bot. 39:793-797.

Perkins, D. D.,1962. Preservation of Neurospora stock cultures with anhydrous silica gel. Can. J. Microbiol. 8:591-594.

Punja, Z. K. and A. Damiani, 1996. Comparative growth, morphology, and physiology of three Sclerotium species. Mycologia 88(5):694-706.

Rayner, R. W., 1970. A mycological colour chart. C.M.I. and Br. Mycol. Soc.

Reitz, L. P., 1948. Reaction of alfalfa varieties, selections, and hybrids to Ascochyta imperfecta. J. Agr. Res. 76:307-323.

Rodríguez, R., K. T. Leath and R. R. Hill, Jr., 1990. Pathogenicity of Phoma medicaginis var medicaginis to roots of alfalfa. Plant Dis. 74:680-683.

Rodríguez, R. and K. T. Leath, 1992. Pathogenicity of Phoma medicaginis var. medicaginis to crowns of alfalfa. Plant Dis. 76:1237-1240.

Sanderson, K. E. and A. M. Srb, 1965. Heterokaryosis and parasexuality in the fungus Ascochyta imperfecta.Amer. J. Bot. 52:72-81.

Schenck, N. C. and J. W. Gerdemann, 1956. Taxonomy, pathogenicity and host parasite relations of Phoma trifolii and Phoma herbarum var. medicaginis. Phytopathology 46:194-200.

Sprague, R., 1929. Host range and life-history studies of some leguminous Ascochytae. Phytopathology 19:917-932.

Taylor, J. W., D. J. Jacobson, and M. C. Fisher, 1999. The evolution of asexual fungi: Reproduction, speciation and classification. Annu. Rev. Phytopathol. 37:197-246. 